doi: https://doi.org/10.15407/microbiolj83.02.042

\title{
LACTOBACILLUS CASEI IMV B-7280 IMMUNOBIOTIC STRAIN INFLUENCE ON THE VIABILITY OF HONEY BEES AND THE CONTENT OF MICROELEMENTS IN THE ORGANISM
}

\author{
I.I. Kovalchuk ${ }^{1}$, R.S. Fedoruk, M.Ya. Spivak', M.M. Romanovych ${ }^{1}$, R. Ya. Iskra \\ ${ }^{1}$ Institute of Animal Biology, NAAS of Ukraine, \\ 38 V. Stusa Str., Lviv, 79034, Ukraine \\ ${ }^{2}$ Zabolotny Institute of Microbiology and Virology, NAS of Ukraine, \\ 154 Acad. Zabolotny Str., Kyiv, 03143, Ukraine \\ e-mail: irenakovalchuk@ukr.net
}

\begin{abstract}
In modern beekeeping it is important to get safe ecological products, stimulate reproduction and increase the resistance of bees to various diseases as well as to protect them from adverse environmental conditions. Due to this, in recent years there has been a tendency to use biologically active preparations and means of protection of natural origin in beekeeping. They may help to avoid many side effects, because the mechanisms of their biological action are significantly different from synthetic and are based on the physiological activation of the organism's protective reactions. The aim of the research was to determine the biological activity of Lactobacillus casei IMV B-7280 immunobiotic strain in honey bees and its influence on their life expectancy and the content of certain mineral elements in organism tissues. Methods. The research was conducted on honey bees of the Carpathian breed, 25-45 individuals in each group, formed in gardens from three bee families from the apiary-vivarium of the Institute of Animal Biology of NAAS of Ukraine. To determine the influence of the immunobiotic, a control (I) and three experimental (II, III, IV) groups were formed. The bees of the experimental groups were fed with sugar syrup together with the immunobiotic strain in various concentrations. The alimentation of bees of control and experimental groups was provided under similar conditions of the laboratory thermostat with microventilation at a temperature of $30.0^{\circ} \mathrm{C}$ and relative humidity of $74-76 \%$ during 12 days of research. During the research period, daily counting of the number of live and dead bees, their motor and forage activity was performed. After feeding, 25 bees were selected from each group and grounded on homogenizer. Got homogenate of tissues was used to search the content of individual trace elements on atomic absorption spectrophotometer SF-115 PC with a computer program for calculating the concentration of elements. Results. The corrective influence of the immunobiotic on the content of $\mathrm{Fe}, \mathrm{Zn}$, $\mathrm{Co}, \mathrm{Cu}, \mathrm{Cd}, \mathrm{Pb}$ in the tissues of bees and their viability depending on the used concentration has been established. Under the conditions of immunobiotic strain addition to the sugar syrup at a concentration from $1 \times 10^{5}$ to $1 \times 10^{9} \mathrm{cells} / \mathrm{ml}$, an increase in the Cobalt content was observed against the background of a decrease in Cadmium and Lead content in tissue samples of bees of the experimental groups compared to the control. The best dynamics in the number of live bees in gardens was observed under the action of high concentration of immunobiotic strain, with the preservation of $100 \%$ of live bees during the first 8 days of immunobiotic use. During the period from $9^{\text {th }}$ to $12^{\text {th }}$ days a decrease in the number of live bees from 88 to $82 \%$ was detected. In the control group, the survival of bees in this period was 7.3 and $2.4 \%$ respectively. Conclusions. The use of Lactobacillus casei IMV B-7280 immunobiotic strain with sugar syrup for feeding bees provides stimulation of their viability, the development of bee colonies, increases the organism's resistance and optimizes the content of certain mineral elements in tissues. The expediency of further researches of the biological activity and safety of the immunobiotic in different experimental models using honey bees is substantiated.
\end{abstract}

Keywords: honey bees, probiotic, Lactobacillus casei, mineral elements, viability, safety of bees. 
In modern beekeeping it is important to get safe and ecological products (honey, royal jelly that do not contain antibiotics); stimulation of reproduction and increasing of bees resistance to parasites and viral diseases, as well as their protection from adverse environmental conditions are also important tasks $[1,2,3]$. In recent years there is a tendency to use preparations of natural origin, which help to avoid many side effects, because the mechanisms of their action are significantly different from synthetic and are based on the physiological activation of the organism's protective reactions.

According to the instructions of the Food and Agriculture Organization (FAO) working group and the World Health Organization, the safety of probiotic cultures is recommended to be determined using a number of tests [4], which also include assessing of their ability to overstimulate the immune response. It has been found that probiotic strain Lactobacillus casei IMV B-7280 with antibacterial, anti-inflammatory and immunomodulatory properties is promising for the development of probiotics [5]. It is recommended to make dietary supplements and medicines based on L. casei IMV B-7280 strain for the prevention and treatment of infectious-inflammatory and other diseases.

Lactobacillus casei IMV B-7280 was characterized by effective therapeutic action in various experimental infectious-inflammatory animal models (infection caused by Staphylococcus and Candida), as well as in models of metabolic disorders of the organism. The physiological influence of this immunobiotic is associated with the normalization of various cavities microbiota and the modulation of the inflammatory response. Its selective positive influence on innate immune factors, its cellular immunity and cytokine profile were also noted $[6,7]$.

Analysis of literature data about the validity and expediency of the use of preparations, which belong to the pharmacological group of probiotics, indicate the possibility of their use for the prevention of a number of diseases and recovery of bees. Defined systematization of probiotics by the complexity of their action, by generations, species composition and the forms of release is of practical interest in the scientific approach in the selection of probiotic strains for beekeeping. After entering the gastrointestinal tract, probiotics have both a direct action on pathogenic and opportunistic microorganisms, and indirect - by activating specific and nonspecific defense systems of the organism [8-10].

In connection with the above-indicated, the purpose was to determine the biological activity of $L$. casei IMV B-7280 immunobiotic strain in vivo on honey bees and its influence on their life expectancy and the content of certain mineral elements in organism tissues.

Material and methods. The research was done on honey bees of Carpathian breed, formed from three bee colonies from the apiary vivarium of the Institute of Animal Biology of the NAAS of Ukraine. The lyophilized probiotic strain $L$. casei IMV B-7280 was used for the research. This strain was isolated in the laboratory from the associated culture of biological material and deposited in the Ukrainian collection of microorganisms of Zabolotny Institute of Microbiology and Virology, NAS of Ukraine. Before each experiment, the viability of lyophilized $L$. casei IMV B-7280 strain was tested by monitoring of its growth on the ManRogosa-Sharpe (MRS) agar media at $37^{\circ} \mathrm{C}$ for 24-48 h.

To perform the research, a control and three experimental groups were formed: Group I control, received daily $1 \mathrm{ml}$ of $50 \%$ sugar syrup (SS) $+1 \mathrm{ml}$ of distilled $\mathrm{H}_{2} \mathrm{O}$; Group II - received daily $1 \mathrm{ml}$ of $50 \% \mathrm{SS}$ with the addition of $1 \mathrm{ml}$ of L. casei IMV B-7280 solution at a concentration of $1 \times 10^{9}$ cells $/ \mathrm{ml}$; Group III - received daily $1 \mathrm{ml}$ of $50 \% \mathrm{SS}$ with the addition of $1 \mathrm{ml}$ of $L$. case $\mathrm{IMV}$ B-7280 solution at a concentration of $1 \times 10^{6}$ cells/ $\mathrm{ml}$; Group IV - received daily $1 \mathrm{ml}$ of $50 \% \mathrm{SS}$ with the addition of $1 \mathrm{ml}$ of L. casei IMV B-7280 solution at a concentration of $1 \times 10^{5}$ cells $/ \mathrm{ml}$. SS and immunobiotic solution were applied to the feeders fixed in the gardens, formed from native beeswax.

Bees of control and experimental groups were kept in cages with a volume of $4 \mathrm{dm}^{3}$ under similar conditions of the laboratory thermostat TS-80M-3 with microventilation at a temperature of $30{ }^{\circ} \mathrm{C}$, humidity of $74-76 \%$ during 12 days of investigation. During the research period, daily control of the number of live and dead bees in the gardens was performed, their motor and forage activity was estimated. On the $12^{\text {th }}$ day, journal records were compared to the actual number of live and dead bees and the daily dynamics of bee survival was determined. The coefficient of average life expectancy (CALE) of bees was calculated by the formula: $\mathrm{CALE}=(\mathrm{a} 1+\mathrm{a} 2+\mathrm{a} 3+\ldots \ldots \mathrm{a} 12) / \mathrm{N}$, where CALE is the coefficient of average life 
expectancy of bees; $a 1+a 2+a 3+\ldots$. a1 $2-$ the number of live bees on the $1^{\text {st }}, 2^{\text {nd }}, 3^{\text {rd }}$, etc. day; $\mathrm{N}$ - the number of bees at the beginning of the research.

After completion of feeding, 25 bees were selected from each group and kept for 10-15 minutes in the freezer. To prepare a homogenate of tissues of the organism, honey bees were grounded, 3 parallel samples from each group weighing $0.5 \mathrm{~g}$ were formed. The obtained homogenates of honey bees' tissues were ash-dried in porcelain crucibles in a muffle furnace at a temperature from $100{ }^{\circ} \mathrm{C}$ at the initial stage to $400-450{ }^{\circ} \mathrm{C}$ at the final stage of ashing. The duration of the whole ashing process was 10-12 hours. After mineralization, the ash was dissolved in $10 \mathrm{ml}$ of $6 \mathrm{~N} \mathrm{HCl}$, filtered and poured into tubes with stoppers to determine the content of $\mathrm{Fe}, \mathrm{Zn}, \mathrm{Co}, \mathrm{Cu}$, $\mathrm{Cd}$, and $\mathrm{Pb}$. The concentration of each of these trace elements was determined by a computer program on an atomic absorption spectrophotometer SF-115PK and expressed in $\mathrm{mg} / \mathrm{kg}$ of natural weight [11].

The research was conducted in accordance with the "General Ethical Principles of Animal Experimentation" adopted by the First National Congress on Bioethics (Kyiv, 2001) and the European Convention for the protection of animals used for experimental and other scientific purposes (Strasbourg, 1986) [12].

All received digital data were processed using the computer program STATISTICA using the method of variation statistics, as well as Excel program from the Microsoft Office-2007 and 2010 service package. Numerical data were presented as the arithmetic mean (M) and standard error $( \pm \mathrm{m})$. Differences between groups were considered statistically significant at $\mathrm{p}<0.05$.

A

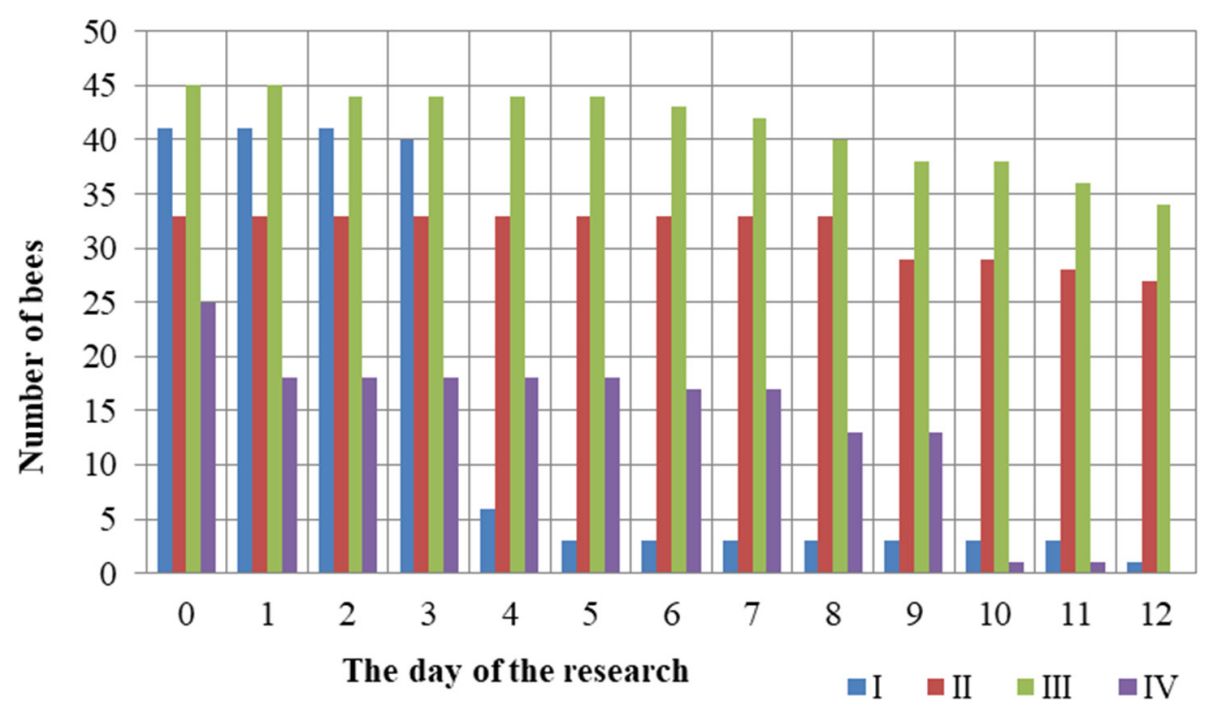

B

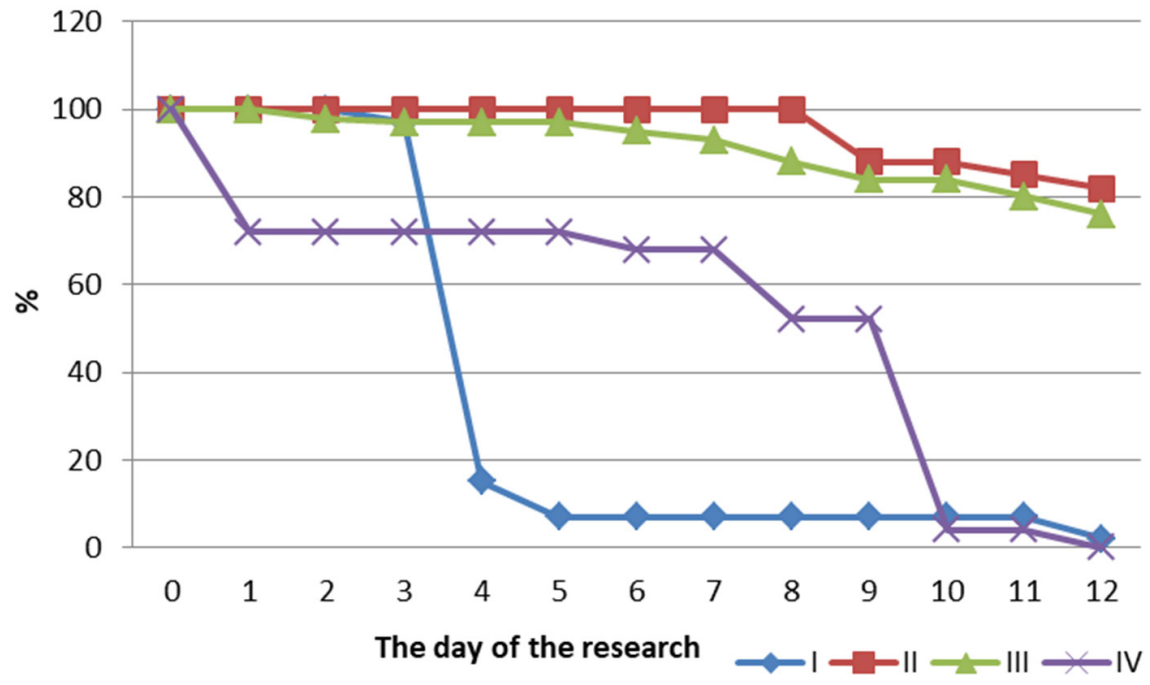

F i g. 1. Daily dynamics of the number of live bees during 12 days. A - changes in the absolute number of bees, pcs.; $B$ - dynamics of changes in the relative number of bees, $\%$ 
Results. The results of research indicate a stimulating influence of the immunobiotic strain on the resistance and viability of honey bees depending on the applied concentration (Fig. 1). It was set that for the first 8 days of the experiment, the highest indicators of viability with $100 \%$ preservation of bees in the gardens was observed in the experimental group II.

The survival of bees in the group I during this period changed from $100 \%$ on the $1^{\text {st }}$ day to $7.31 \%$ on the $8^{\text {th }}$ day. Among 3 experimental groups the lowest indicators of bees preservation during this period was observed in the experimental group IV, which in addition to $1 \mathrm{ml}$ of $50 \%$ $\mathrm{SS} /$ garden/day obtained $1 \mathrm{ml}$ of immunobiotic solution at a concentration of $1 \times 10^{5}$ cells $/ \mathrm{ml}$. On the $9-12^{\text {th }}$ days of the research the better bee preservation was noted in the experimental group III (their number decreased from 97.7 to $75.5 \%$ ) in comparison with the control. The highest preservation of bees from $9^{\text {th }}$ to $12^{\text {th }}$ days was observed in the group II - their number decreased from 87.9 to $81.8 \%$. The number of live bees in the group IV decreased significantly on the $10^{\text {th }}$ days from 52 to $4 \%$ with their complete death on the $12^{\text {th }}$ day.

Analysis of the CALE parameter calculation during 12 days showed a different strength of the pronounced influence of immunobiotic on the resistance of the organism of bees (Fig. 2). The best result in terms of life expectancy of bees was noted for group II, which was equal to 11.4 conventional units (c.u.) under the action of immunobiotic at a concentration of $1 \times 10^{9}$ cells $/ \mathrm{ml}$.

Life expectancy of bees of the group III, which were fed with SS with the addition of immunobiotic strain at a concentration of $1 \times 10^{6}$ cells $/ \mathrm{ml}$, was 10.9 c.u. An even lower life expectancy result (6.1 c.u.) was observed for bees of experimental group IV, which received a solution of immunobiotic at a concentration of $1 \times 10^{5} \mathrm{cell} / \mathrm{s} / \mathrm{ml}$.

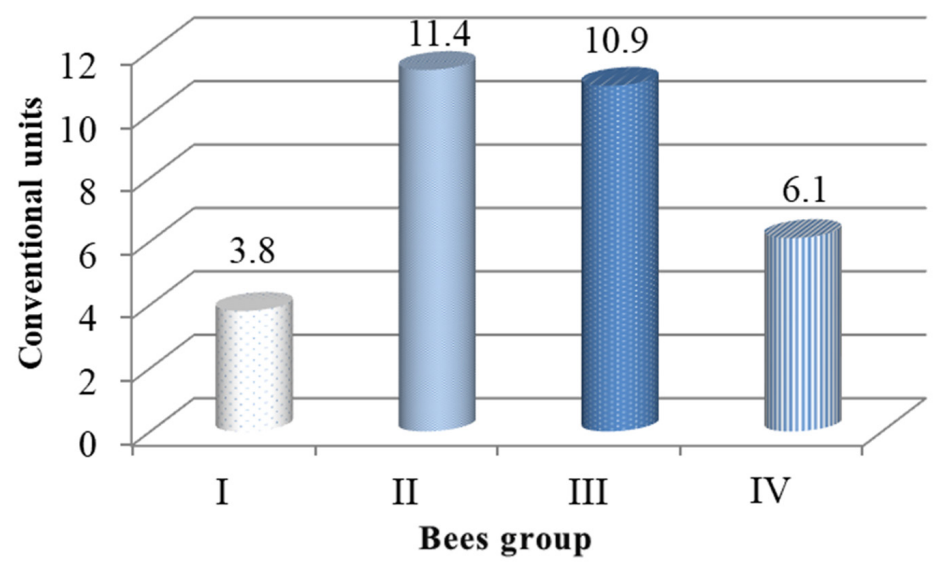

F i g.2. Coefficient of average life expectancy (CALE) of bees during the research, c.u.

Thus, the highest number of live bees in the gardens was observed in group II, with the preservation of $100 \%$ of live bees during first 8 days and decreasing from 87.9 to $81.8 \%$ from the $9^{\text {th }}$ to $12^{\text {th }}$ day and CALE -11.4 c.u. Compared to group II, from $9^{\text {th }}$ to $12^{\text {th }}$ day the preservation of bees of III (from 100 to $75.5 \%$ ) and IV (from 72.0 to $4.0 \%$ ) experimental groups was lower, against the background of rapid decrease of their number (from 100 to $2.4 \%$ ) in the control group.

It is known that the organism of honey bees is able to actively deposit such mineral elements as $\mathrm{Cu}, \mathrm{Zn}, \mathrm{Co}, \mathrm{Fe}$. Macro- and microelements in the organism of animals, including honey bees, are part of the active centers of enzymes as a part of cofactors of biochemical catalysis in the reactions of proteins, lipids and carbohydrates metabolism. However, it is known that excessive intake of certain heavy metals $-\mathrm{Pb}, \mathrm{Cu}$ and $\mathrm{Cd}$ in the organism of bees reduces the number of dominant cations of certain metals in the circulatory system of hemolymph [13]. According to the results of the research, an increase in the level of Co against the background of $\mathrm{Cd}$ and $\mathrm{Pb}$ reduction in samples of bees of experimental groups compared to the control (Table 1) was observed.

The need of bees for micro- and macroelements is provided by their receipt with plant pollen, water and nectar, however, depends largely on the synergistic or antagonistic relationships between the various, including insufficiently studied elements. The accumulation of iron in the organism 
of bees during ontogenesis is uneven in nature and its metabolism changes under the influence of external factors. Excessive intake of iron is characterized by an increase in its concentration in tissues regardless of the stage of bee development, which entails a change in its distribution in the organism [14]. The addition of immunobiotic to the syrup decreased $\mathrm{Fe}$ concentration in the tissues of bees of II and III groups $(p<0.05)$, but increased its level in the experimental group IV $(\mathrm{p}<0.05)$ compared to the control group I.

\section{Table 1}

The content of mineral elements in the homogenate of bees tissues under the conditions of their feeding with SS and immunobiotic (IB), $\mathrm{mg} / \mathrm{kg}$

\begin{tabular}{|c|c|c|c|c|}
\hline \multirow{3}{*}{$\begin{array}{l}\text { Trace } \\
\text { elements }\end{array}$} & \multicolumn{4}{|c|}{ Groups of honey bees } \\
\hline & \multirow{2}{*}{$\begin{array}{c}\text { Control } \\
\text { Group I, } 1 \mathrm{ml} \mathrm{50 \%} \\
\text { SS }+1 \mathrm{ml} \mathrm{H}_{2} \mathrm{O}\end{array}$} & \multicolumn{3}{|c|}{ Experimental } \\
\hline & & $\begin{array}{l}\text { Group II, } 1 \mathrm{ml} 50 \% \mathrm{SS} \\
\quad+1 \mathrm{ml} \ll \mathrm{IB} » 1 \times 10^{9}\end{array}$ & $\begin{array}{l}\text { Group III, } 1 \mathrm{ml} 50 \% \\
\mathrm{SS}+1 \mathrm{ml} \ll \mathrm{IB} » 1 \times 10^{6}\end{array}$ & $\begin{array}{l}\text { Group IV, } 1 \mathrm{ml} 50 \% \\
\mathrm{SS}+1 \mathrm{ml} \ll \mathrm{IB} » 1 \times 10^{5}\end{array}$ \\
\hline $\mathrm{Fe}$ & $79.90 \pm 4.87$ & $71.80 \pm 2.95$ & $67.50 \pm 2.25^{*}$ & $94.20 \pm 2.63^{*}$ \\
\hline $\mathrm{Zn}$ & $54.60 \pm 2.33$ & $42.70 \pm 1.84^{* *}$ & $62.50 \pm 2.13^{*}$ & $55.90 \pm 2.14$ \\
\hline Co & $0.20 \pm 0.009$ & $0.20 \pm 0.009$ & $0.60 \pm 0.05^{* *}$ & $0.90 \pm 0.03^{* * *}$ \\
\hline $\mathrm{Cu}$ & $7.20 \pm 0.34$ & $4.80 \pm 0.11^{* *}$ & $9.80 \pm 0.47^{* *}$ & $9.90 \pm 0.22^{* *}$ \\
\hline $\mathrm{Cd}$ & $0.09 \pm 0.005$ & $0.04 \pm 0.002^{* * * *}$ & $0.06 \pm 0.002 * *$ & $0.10 \pm 0.005$ \\
\hline $\mathrm{Pb}$ & $0.80 \pm 0.06$ & $0.60 \pm 0.04$ & $0.50 \pm 0.06^{*}$ & $0.70 \pm 0.05$ \\
\hline
\end{tabular}

Legend: difference relative to control: * $-\mathrm{P}<0.05$; ** $-\mathrm{P}<0.01$; *** $-\mathrm{P}<0.001$.

It is known that $\mathrm{Zn}$ is important for the organism's vital functions which had an influence on the normal development of bee brood and the viability of bee family. This trace element is required for the functioning of more than 100 enzymes, including DNA and RNA polymerases, carboxypeptidases, oxidoreductases, transferases, dehydrogenases. These enzymes are associated with the metabolism of carbohydrates, proteins, nucleic acid and heme synthesis, $\mathrm{CO}_{2}$ transport, etc. [15]. The content of $\mathrm{Zn}$ in the tissues of mammals and plants is characterized by significant variability. Its content in the organism of honey bees also varies depending on the age of the insects. Regarding the initial level of $\mathrm{Zn}$ in the organism tissues, its decrease was observed under the conditions of immunobiotic feeding in the experimental group II ( $p<0.01)$ against the background of an increase in the experimental group IV $(\mathrm{p}<0.05)$ compared to the control group.

It is known that Co increases the biosynthesis of proteins and the concentration of $\gamma$-globulins in the fractions of total hemolymph protein, as well as lipid synthesis and hemolymphogenesis [16]. The highest Co content was found in bees of III and IV experimental groups ( $p<0.001)$ fed with immunobiotic at a concentration of $1 \times 10^{5}$ and $1 \times 10^{6}$ cells $/ \mathrm{ml}$ respectively.

It should be noted the increase of copper level in the tissues of bees from experimental groups III and IV. However, the use of immunobiotic at a higher concentration of $10^{9}$ cells $/ \mathrm{ml}$ (experimental groups II) caused a probable decrease of copper concentration, which may be due to the inhibitory influence of this concentration on the absorption of copper in the digestive tract of bees and accumulation in organism tissues.

$\mathrm{Pb}$ and $\mathrm{Cd}$ do not accumulate evenly in the tissues of the organism of honey bees. The content of Cd was 2.2 times lower $(\mathrm{p}<0.001)$ in the tissues of bees of group II and 1.5 times lower - in group III $(\mathrm{p}<0.01)$ compared to the control. The $\mathrm{Pb}$ content was characterized by a lower level in the tissue samples of bees from experimental groups II and III ( $p<0.05)$ compared to the control group.

Therefore, the addition of L. casei IMV B-7280 immunobiotic strain to SS during the feeding of bees stimulates their viability in the applied concentrations, which is more pronounced at a concentration of $1 \times 10^{9}$ and $1 \times 10^{6}$ cells. The influence of concentration $1 \times 10^{5}$ cells was characterized by lower preservation of bees, but the number of live bees and the coefficient of average life expectancy were greater than these values in the control.

Discussion. The results of the research showed that under the influence of the immunobiotic there was a positive dynamics of preservation of bees for 8 days with lower death compared to the control group during this period. Under the conditions of immunobiotic application, no deterioration 
of the physiological state was observed in the motor and foraging activity of bees in the II and III experimental groups. In particular, bees of these groups were characterized by better motor activity and SS with immunobiotic eating, which may indicate its stimulating action in the applied concentrations compared to the experimental group with a lower concentration.

According to the literature, the use of probiotics has a positive influence on the growth and development of the pertrophic membrane in the midgut [17]. Its thickness is positively correlated with the life expectancy of bees. It should be noted that the density of the pertrophic membrane depends on the permeability of pathogenic microorganisms in the digestive tract, as well as the immunity of bees. The use of a concentrate of lactic acid bacteria leads to an increase in life expectancy by $9.5 \%$, the mass of rectums with undigested remains decreases by $18.0 \%$, but does not have an influence on the mass of milk in the cells with larvae $[18,19]$.

Stimulating effects of lactobacilli are appeared in the mechanisms of gastrointestinal tract reticuloendothelial system activation and the production of a number of cytokines, providing a balance between humoral and cell-mediated immunity. The most important mechanism of lactobacilli and obligate microbiota interaction with the host organism, which is directed at homeostasis maintaining, is the stimulation of the production of a number of cytokines [20,21].

Physiological functions of the intestinal microbiota of bees are diverse, but one of the main functions is to ensure colonization resistance $-\mathrm{a}$ set of mechanisms, providing stability to useful microbiota and prevent colonization of intestines by pathogenic microorganisms. The symbiotic intestinal microbiota is important for the life of bees. This is due to bacterial enzymes that break down carbohydrates and convert nectar into honey and take part in protein assimilation from nutritional components [22]. Decreased life expectancy of bees in the experimental group that received immunobiotic at a concentration of $1 \times 10^{5}$ cells/ $\mathrm{ml}$ obviously associated with low assimilation of carbohydrate components of the feed. An inhibitory factor in these processes can also be a decrease in the intensity of water removal from their organism through the body coverings and respiratory system.

The balance of chemical elements in living organisms is the basis of their normal vital activity. It is known that synergistic or antagonistic interactions have the same significance as their deficiency or toxicity. The main amount of trace elements enters the organism of honey bees with plant pollen, which they absorb from the soil. Much less with nectar and water. A significant amount of trace elements is included in the metabolic processes of the organism of bees and is actively used in biochemical reactions in the process of nectar and pollen processing. It is proved that mineral components, including $\mathrm{Co}, \mathrm{Zn}, \mathrm{Fe}$, pollen and nectar of forage plants play an important role in the functioning of the microbiota, carbonatebicarbonate buffer system and regulation of acid-base balance in the digestive system. Their role in the formation of the organism's resistance and viability of bees and the functioning of the potassium-histidine-glutamine system in hemolymph is especially important [23].

According to the results of the research, the corrective influence of different concentrations of $L$. casei IMV B-7280 probiotic strain on the assimilation of certain mineral elements in the digestive tract of bees was defined. This caused differences in the content of $\mathrm{Fe}, \mathrm{Zn}, \mathrm{Co}, \mathrm{Cu}, \mathrm{Cd}$, $\mathrm{Pb}$ in the tissues of the organism of honey bees. It is known from the literature that increasing the daily use of iron compared to physiological needs leads to inhibition of copper, manganese and cobalt absorption, and hence to their deficiency in the organism. However, the absorption of iron by mitochondria of erythrocytes is significantly reduced in the case of acute copper deficiency. It is possible that such connections are due to synergistic and antagonistic aspects of the interaction of these trace elements. Analysis of the causal relationships of the content of these elements in tissues indicates the different ability of their biotransformation in the organism under the action of various factors [24].

It should be noted that feeding of bees with SS with $L$. casei IMV B-7280 was characterized by an increase in the content of copper. It is known that $\mathrm{Cu}$ is actively involved in biochemical processes as a part of electron-transfer proteins that carry out the oxidation reactions of organic substrates with molecular oxygen, and is also part of the active centers of amino oxidases. In addition, under the influence of $L$. casei IMV B-7280, the participation of $\mathrm{Cu}$ in the catabolism and inactivation of a number of physiologically active biogenic amines, namely histamine and serotonin, may have increased. Because it has been proven that histamine is found in large quantities in bee poison [25]. The potential places of accumulation of copper and its metabolites in the organism of bees, in addition to the colon, may be nerve nodes and fat body. Excess 
copper causes zinc and molybdenum deficiency, leading to immunological disorders caused by zinc deficiency [26].

It should be noted that Cobalt plays an important role in metabolic and immunobiological processes, has a positive influence on the growth and development of the bee family, its viability and productivity. The level of Co in the organism of insects, including bees, has an influence on the content of total protein in the hemolymph depending on the age and functional characteristics of their organism. In some cases, this action occurs due to an increase in beta and gamma globulins, but the content of alpha globulins is reduced. However, in other cases - due to an increase in albumin, beta and gamma globulins with a simultaneous decrease in alpha globulins. This testifies a corrective influence of Cobalt on the level of immunoglobulins in hemolymph, which increases the resistance of bees and immunobiological activity of the organism [27].

It is proved that together with water, which is adsorbed by hemolymph from the contained goiter, metals, including toxic, are transported through its walls. They are accumulated in small quantities in the fat body and other anatomical structures of bees' organism [28]. Excess minerals, including $\mathrm{Pb}$ and $\mathrm{Cd}$, are excreted by excretory organs. $\mathrm{Pb}$ and $\mathrm{Cd}$ are mostly accumulated in the rectal glands of honey bees, which affects the increase in their water content. Obviously, this occurs due to inhibition of the rectal glands function, weakening the resorption of water from their secretory fluid, which can inhibit the vital processes of bees. Decreased viability of bees, apparently, is also associated with a decrease in the intensity of water excretion from the organism of bees through the body coverings and respiratory system $[29,30]$. Characteristically, the content of $\mathrm{Cd}$ and $\mathrm{Pb}$ was lower in the tissue samples of bees from experimental groups II and III ( $p<0.05-0.001)$ compared to the control. This may indicate the optimizing influence of the immunobiotic at a concentration of $1 \times 10^{6}$ cells $/ \mathrm{ml}$ on the level of harmful metals in the rectal glands.

Thus, probiotics can have stimulating action on the resistance and viability of the organism of honey bees. Under the conditions of research of their influence it is expedient to define concentration, schemes and dosage of probiotics.

Conclusions. The results of the researches showed that $L$. casei IMV B-7280 immunobiotic strain is promising for the development of a preparation with the ability to stimulate the resistance and viability of bees and the development of bee colonies. The use of $L$. casei IMV B-7280 immunobiotic strain have positive influence on the number of bee family. Based on the obtained results, it is possible to recommend further research of the biological activity of $L$. casei IMV B-7280 immunobiotic strain and safety of its use in various experimental models, as well as in combination with organic compounds of individual trace elements.

\section{ВПЛИВ ІМУНОБІОТИЧНОГО ШTAMУ LASTOBACILLUS CASEI IМВ В-7280 НА ЖИТТЕЗДАТНІСТЬ МЕДОНОСНИХ БДЖІЛ ТА ВМІСТ МІКРОЕЛЕМЕНТІВ В ОРГАНІЗМІ}

\section{I.I. Ковальчук ${ }^{1}$, Р.С. Федорук', М.Я. Співак ${ }^{2}$, М.М. Романович ${ }^{I}$ Р.Я. Іскра}

${ }^{1}$ Інститут біології тварин НААН України, вул. Василя Стуса, 38, Львів, 79034, Украӥна

${ }^{2}$ Інститут мікробіології і вірусології ім. Д. К. Заболотного НАН Украӥни, вул. Акад. Заболотного, 154, Київ, 03143, Украӥна

Резюме

У сучасному бджільництві актуальним є отримання безпечної екологічної продукції, стимуляція розмноження і підвищення стійкості бджіл до різних хвороб, а також захист їх від дії несприятливих умов навколишнього середовища. У зв'язку з цим в останні роки проявляється тенденція до застосування у бджільництві біологічно активних препаратів і засобів захисту природного походження. Це дозволяє уникнути багатьох побічних ефектів, оскільки механізми їх біологічної дії істотно відрізняються від синтетичних $\mathrm{i}$ грунтуються на фізіологічній активації захисних реакцій організму. Метою досліджень було визначення біологічної активності імунобіотичного штаму Lactobacillus casei IMB B-7280 у медоносних бджіл та його впливу на тривалість їх життя i вміст окремих мінеральних елементів у тканинах організму. Методи. Дослідження проведено на медоносних бджолах карпатської породи, по 25-45 особин у кожній групі, сформованих у садки від трьох бджолосімей з пасіки-віварію Інституту біології тварин НААН України. Для визначення дії імунобіотика було сформовано контрольну (I) i три дослідні (II, III, IV) групи. Бджоли дослідних груп отримували підгодівлю цукровим сиропом 
разом з імунобіотиком у різних концентраціях. Утримання бджіл контрольної та дослідних груп забезпечувалося за аналогічних умов лабораторного термостату з мікровентиляцією при температурі $30{ }^{\circ} \mathrm{C}$ і відносній вологості 74-76 \% впродовж 12 діб досліджень. У період досліджень виконували щодобовий підрахунок кількості живих i мертвих бджіл, оцінювали їх рухову і кормову активність. Після завершення підгодівлі відбирали по 25 бджіл 3 кожної групи і подрібнювали їх на гомогенізаторі. Одержаний гомогенат тканин організму медоносних бджіл використовували для дослідження вмісту окремих мікроелементів на атомно-абсорбційному спектрофотометрі СФ-115 ПК з комп'ютерною програмою підрахунку концентрації елементів. Результати. Встановлено вплив імунобіотика на вміст $\mathrm{Fe}, \mathrm{Zn}, \mathrm{Co}, \mathrm{Cu}, \mathrm{Cd}$, $\mathrm{Pb}$ в тканинах організму бджіл і їх життєздатність залежно від застосованої концентрації. За умов додавання до цукрового сиропу імунобіотика у концентрації від $1 \times 10^{5}$ до $1 \times 10^{9}$ клітин/мл спостерігали зростання вмісту кобальту на тлі зниження

1. Conti ME, Botrè F. Honeybees and their products as potential bioindicators of heavy metals contamination. Environmental Monitoring and Assessment. 2001; 69:267.

2. Adam Roman Levels of Copper, Selenium, Lead, and Cadmium in Forager Bees Pol. J Environ Stud. 2010; 19(3):663-669.

3. Bogdanov S, Haldimann M, Luginbühl W. Minerals in honey: environmental, geographical and botanical aspects. Journal of Apicultural Research. 2007; 46(4):269-275.

4. Guidelines for the Evaluation of Probiotics. Food Report of a Joint FAO/WHO Working Group on Drafting Guidelines for the Evaluation of Probiotics in Food London Ontario, Canada; April 30 and May 1, 2002.

5. Beregova TV, Lazarenko LM, Savchuk OM, Sichel LM, et al. Probiotic strains of Lactobacilli and bifidobacteria alter pro- and anti-inflammatory cytokines production in rats with monosodium glutamate-induced obesity. Fiziol Zh. 2017; 63(1):17-25.

6. Lazarenko LM, Babenko LP, Mokrozub VV, Demchenko OM, Bila VV, Spivak MYa. Effects of oral and vaginal administration of probiotic кадмію і свинцю в зразках тканин бджіл дослідних груп у порівнянні з контролем. Найкраща динаміка за кількістю живих бджіл у садках відзначена у групі, що отримувала імунобіотик у високій концентрації, зі збереженням 100 \% живих бджіл впродовж перших 8 діб його застосування. У період з 9 по 12 добу встановлено зниження кількості живих бджіл з 88 до 82 \%. У контрольній групі збереженість бджіл у цей період становила 7,3 i 2,4 \% відповідно. Висновки. Додавання імунобіотичного штаму L. casei IMB B-7280 до цукрового сиропу для підгодівлі бджіл забезпечує стимуляцію їх життєздатності, розвиток бджолиних сімей, підвищення резистентності організму та оптимізацію вмісту окремих мінеральних елементів у тканинах. Обгрунтовано доцільність подальших досліджень біологічної активності та безпечності імунобіотика за різних експериментальних моделей з використанням медоносних бджіл.

Ключові слова: медоносні бджоли, пробіотик, лактобактерії, мінеральні елементи, життєздатність, збереженість бджіл.

bacteria on the vaginal microbiota and cytokines production in the case of experimental Staphylococcosis in mice. Mikrobiol Z. 2017; 79(6):10519.

7. Starovoitova S, Oryabinskaya L. Development of the composition of the polystrain probiotic on basis of the bacteria of genus Lactobacillus. $21^{\text {st }}$ International CODATA Conference Scientific Information for Society - from Today to the Future". Kyiv; 2008:170-171.

8. Gucol A, Kovalskyi Y, Kovalska L, Gucol N. [Effect of probiotics on growth, development and economically useful traits honeybees]. Scientific Messenger LNUVMBT named after S. Z. Gzhytskyj. 2017; 19(74):235-238. Ukrainian.

9. Kacaniova MM, Kacaniova S, Pavlicova P. Hascik, et al. Microbial communities in bees, pollen and honey from Slovakia. Asta Microbiol Jmm H. 2009; 56:285-295.

10. Holzapfel WH, Haberer P, Geisen R. Taxonomy and important features of probiotic microorganisms in food and nutrition. Am J Clin Nutr. 2001; 73:365373.

11. Vlizlo VV, Fedoruk RS, Ratych IB. [Laboratory methods of investigation in biology, stock-breed- 
ing and veterinary]. Reference book. Lviv: SPOLOM, 2012; 764. Ukrainian.

12. European Community, 2005. 1459/2005/EC. Commission Regulation (EC) No 1459/2005 of 8 Sept. 2005 amending the conditions for authorisation of a number of feed additives belonging to the group of trace elements. Offic J Europ Union L233. 2005; 8-10.

13. Pshenichnaya EA, Sonitsyn VM. [Influence of BAS on the content of some chemical elements in the body of bees and honey]. Journal of Beekeeping. 2011; 5:15-18. Russian.

14. Brodschneider R, Crailsheim K. Nutrition and health in honey bees. Apidologie. 2010; 41:278294.

15. Prasad AS. Zinc: role in immunity, oxidative stress and chronic inflammation. Curr Opin Clin Nutr Metab Care. 2009; 12(6):646-652.

16. Chan QWT, Howes CG, Foster LJ. Quantitative comparison of caste differences in honeybee hemolymph. Mol Cell Proteomics. 2006; 5(12):2252-2262.

17. Szymas B, Landowska A, Kazimierczak M. Histological structure of the Midgut of honey bees (Apis MelliferaL.) Feed Pollen Substitutes Fortified with Probiotics. Journal of Apicultural Science. 2012: 56(1):5-12.

18. Kacaniova M, Chlebo RM, Kopernicky A. Trakovicka Microflora of the Honeybee Gastrointestinal Tract. Folia Microbiol. 2004; 49 (2):169171.

19. Kacaniova M, Pavlicova S, Hascik P. Microbial communities in bees, pollen and honey from Slovakia. Asta Microbiol Jmm H. 2009; 56:285-295.

20. Forsgren E, Olofsson CT, Vasquez AI. Novel lactic acid bacteria inhibiting Paenibacillus larvaein honey bee larvae. Apidologie. 2009; 41:99-108.

21. Maldonado Galdeano C, Perdigon G. The probiotic bacteria Lactobacillus casei induces activation of the gut mucosal immune system through the innate immunity. Clin Vaccine Immunol. 2005; 13: 219-226.

22. Fredrick JL, Douglas BR, Frank JS, Heather RM, Newton LG. Saccharide breakdown and fermentation by the honey bee gut microbiome. Environmental Microbiology. 2014; 17(3):796-815.

23. Hartfelder K, Bitondi M, Brent CS, GuidugliLazzarini KR, Simoes ZL, Stabeniner A. Physio logy and biochemistry of honey bees. Journal of Apicultural Research. 2013:504-508.

24. Kovalchuk I, Dvylyuk I, Lecyk Y, Dvylyuk I, Gutyj B. Physiological relationship between content of certain microelements in the tissues of different anatomic sections of the organismof honey bees exposed to citrates of argentum and cuprum. Regulatory Mechanisms in Biosystems. 2019; 10(2):177-181.

25. Şapcaliu A, Pavel C, Savu V, Matei M, Rădoi I. Biochemical and Cytological Investigations on Haemolymph of Apis Mellifera Carpathica Bee in Stressful Conditions. Bulletin UASVM Animal Science and Biotechnologies. 2010; 67 (1-2):313-320.

26. Huang Z. Honey bee nutrition. American Bee Journal. 2010; 150:773-776.

27. Acevedo F, Vesterberg O. Nickel and cobalt activate complement factor $\mathrm{C} 3$ faster than magnesium. Toxicology. 2003; 185(1-2):9-16.

28. Kovalchuk II, Fedoruk RS. [Melliferous bees and honey are bioindicator contamination of environment by heavy metals]. The Animal Biology. 2008; 10(1-2):24-32. Ukrainian.

29. Breed MJ, Guzman-Nova E, Hunt GJ. Defensive behavior of honey bees: Organization, genetics, and comparisons with other bees. Annu Rev Entomol. 2004; 49:271-98.

30. Stalidzans E, Berzonis A. Temperature changes above the upper hive body reveal the annual development periods of honey bee colonies. Comput Electron Agric. 2013; 90:1-6.

Received 17.09.2020 